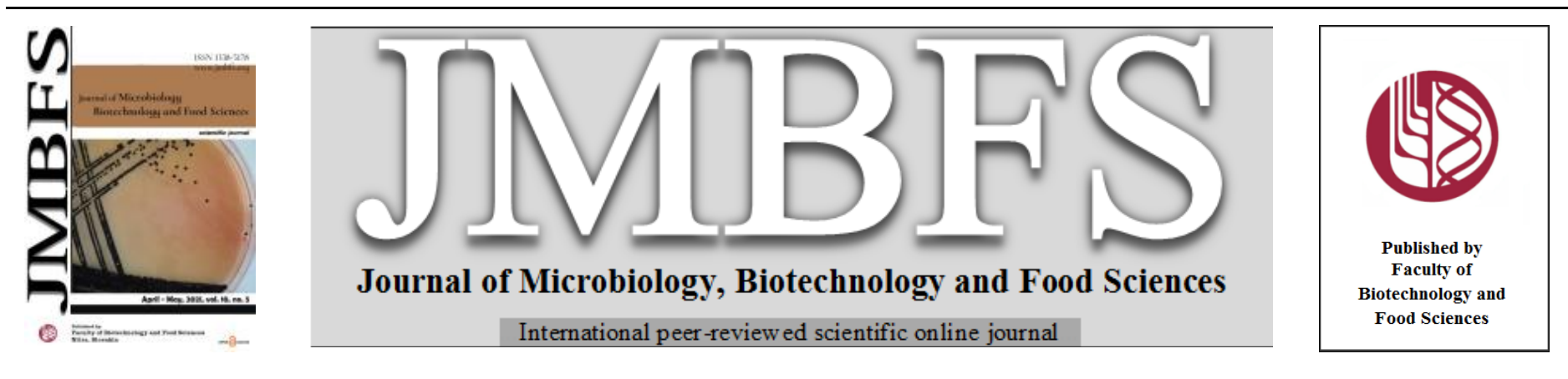

\title{
CONJUGATED LINOLEIC ACID-ENRICHED DAIRY PRODUCTS: A REVIEW
}

\author{
Mihaela Ivanova $*^{1}$ \\ Address(es): Mihaela Ivanova, \\ ${ }^{1}$ University of Food Technologies, Technological Faculty, Department of Milk and Dairy Products, 26, Maritsa Blvd., 4002 Plovdiv, Bulgaria, phone number: \\ +35932603783 .
}

*Corresponding author: mihaela_18bg@abv.bg

https://doi.org/10.15414/jmbfs.3609

ARTICLE INFO

Received 19.8.2020

Revised 6. 12. 2020

Accepted 7. 12. 2020

Published 1. 4. 2021

Regular article OPEN OACCESS

\begin{abstract}
Conjugated linoleic acid (CLA) is a family of more than 28 isomers of linoleic acid wherein the isomers cis-9, trans-11 (rumenic acid) and trans-10, cis-12 are the most abundant. It is associated with a number of potential health benefits for human organism. Many foods are a good source of it but it is mosty found in meat and dairy products, derived from ruminants. Dairy products contain CLA in different amounts. The enrichment of these products with CLA is appropriate given the lower CLA content in these products in comparison with the recommended health intake. Modification of CLA concentration can be done by specific animal feeding and diet modification, by direct CLA supplementation in the form of oils or by addition of specific starter culture. The influence of technological treatments on the stability of the final product during storage and maturation is still not completely elucidated. There is a need for further studies on the physiological effects of CLA isomers on humans. The purpose of this review is to summarize the possibilities for increasing CLA content in milk and dairy products and to determine the possible effects of this enrichment on product stability sensory, chemical, microbiological profile, shelf life and potential health effects of the obtained products.
\end{abstract}

Keywords: conjugated linoleic acid, milk, dairy products, functional foods

\section{INTRODUCTION}

In recent years, there was an increased discussion about the role of milk fat and its components and their influence on human health. Milk fat is a natural source of high valuable biologically active compounds such as phospholipids, fatsoluble vitamins, short-chain fatty acids and conjugated linoleic acid (CLA) (Bhat and Bhat, 2011). It is believed that the positive effects of these milk fat components are in predominance if compared with the negative influence of saturated fatty acids on human health. Liesbeth et al. (2010) demonstrated that cis-9, trans-11 CLA, presented in significant amounts in the milk of pasture-grazed cows, might offset the adverse effect of the saturated fat content of dairy products. Further research on this dependence can be made in order to determine even more precisely the predominance of the positive health effects of the fatty acid profile of dairy products over the often wrongly alleged unhealthy ones.

CLA is naturally formed in the rumen as an intermediate product in the digestion of dietary fat (Song and Kennelly, 2002). According to Meraz-Torres and Hernandez-Sanchez (2012), it is synthetized by two ways - the first is by incomplete biohydrogenation of linoleic and linolenic acids in the rumen by the endogenous bacteria and the second one is the conversion of transvaccenic acid to CLA in the animal tissues which represents $60-95 \%$ of the total CLA in the foods produced from animals.

CLAs are conjugated dienes of linoleic acid (Fig.1). This name refers to a group of positional and geometric isomers of linoleic acid, characterised by a conjugated system of double bonds, separated by one single bond (National Centre for Biotechnology Information, 2020).
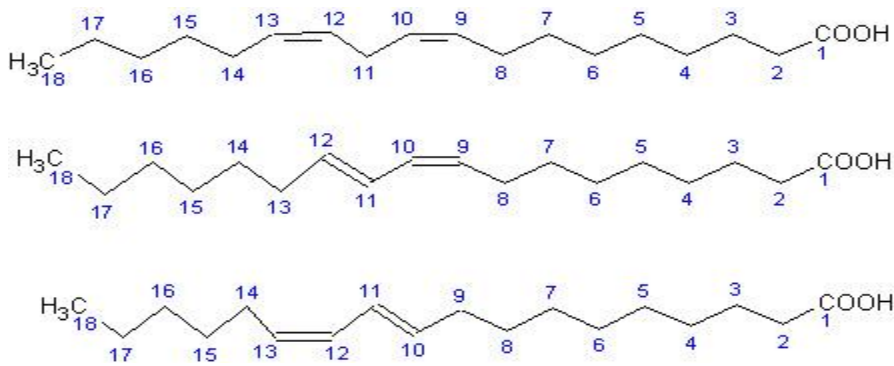

Figure 1 Chemical formulas of CLA isomers
There are 28 potential CLA isomers. The most common isomers are cis-9, trans11, and trans-10, cis-12 of which rumenic acid (C18:2 cis-9, trans-11) is dominant in milk fat (Virsangbhai et al., 2020).

Natural CLA content in milk and dairy products is presented in Table 1 . Markiewicz-Keszycka et $\boldsymbol{a l}$. (2013) reviewed the fatty acid profile of milk and found that sheep milk was the richest source of conjugated linoleic acid in comparison with cow and goat milk. This fact was confirmed by Prandini $\boldsymbol{e t}$ al. (2011). Different factors, such as diet, production system, breed, or stage of lactation could influence on the CLA content in milk and dairy products respectively. Recent review (Ahmad et al., 2019) declared dairy products with natural CLA concentration ranging from 3.4 to $10.7 \mathrm{mg} / \mathrm{g}$ fat in milk.

Dairy products originating from various producers and from various countries were characterized by similar contents of CLA and diversified contents of trans isomers of C18:1 and C18:2 acids (Paszczyk et al., 2012a) which impose the need of a broader analysis of similar products prepared under different conditions. It can be seen that in some types of dairy products, such as yoghurt, butter, ice cream, fresh cheeses and white pickeled cheeses, large deviations in the reported natural CLA content were found. This imposes on researchers the need to optimize methods of analysis, to seek comparability of results and is an opportunity for future research.The effect of initial fat content on the CLA content of the finished product must be investigated in more depth. The highes CLA content in all analysed cheeses was found in hard cheeses with long ageing time while white pickled cheeses, which were produced without ageing or with short ageing time, contained only low amounts of CLA. From the presented data it is evident that there is a need to study the influence of various factors on the natural content of CLA in dairy products.

Collomb et al. (2006) summarized CLA variation and physiological effects on milk fat quality and quantity. According to Kirchnerová et al. (2012) it is not possible to influence some groups of desirable fatty acid, e.g. CLA, without the influence on other fatty acids. In this view, it is recommended that studies dedicated on the current topic provide an overall assessment of the fatty acid profile of the analysed products. Natural CLA concentrations are not sufficient to demonstrate specific health promoting effects. CLA enrichment of foods can cause a number of beneficial health effects on animal and on human organism. In recent scientific research, authors suggested that enrichment of dairy products with CLA may positively influence on human immune system stimulation, may 
present antihypertensive, anticarcinogenic, and antiatherogenic effects and promotes the health benefits by body weight loss (Yang et al., 2015).

Table 1 Natural CLA content in milk and dairy products

\begin{tabular}{|c|c|c|c|c|c|}
\hline Type of product & $\begin{array}{l}\text { CLA } \\
\text { concentration, } \\
\mathrm{mg} / \mathrm{g} \text { fat }\end{array}$ & Source & Type of product & $\begin{array}{l}\text { CLA concentration, } \\
\mathrm{mg} / \mathrm{g} \text { fat }\end{array}$ & Source \\
\hline Fresh dairy products & & & Cheeses & & \\
\hline Cow milk & $4.5-5.7$ & $\begin{array}{l}\text { Markiewicz-Kęszycka et al. } \\
\text { (2013) }\end{array}$ & Mozzarella & 4.9 & Chin et al. (1992) \\
\hline Sheep milk & 7.6 & $\begin{array}{l}\text { Markiewicz-Kęszycka et al. } \\
\text { (2013) }\end{array}$ & Mold cheeses & $2.5-8.1$ & Paszczyk et al. (2012a) \\
\hline Goat milk & 4 & Cossignani et al. (2014) & $\begin{array}{l}\text { Bloomy mould } \\
\text { cheese }\end{array}$ & $5.4-8.8$ & $\begin{array}{l}\text { Paszczyk and } \\
\text { Rafałowski (2015) }\end{array}$ \\
\hline Buffalo milk & 4.2 & $\begin{array}{l}\text { Van Nieuwenhove et al. } \\
(2007 b)\end{array}$ & Blue-veined cheeses & $3.5-11$ & $\begin{array}{l}\text { Paszczyk and } \\
\text { Rafałowski (2015) }\end{array}$ \\
\hline Homogenized milk & 5.5 & Chin et al. (1992) & $\begin{array}{l}\text { Feta and Greek } \\
\text { cheeses }\end{array}$ & 8 & Zlatanoz et al. (2002) \\
\hline Yoghurt & $0.9-4.8$ & $\begin{array}{l}\text { Chin et al. (1992) } \\
\text { Paszczyk and Rafalowski } \\
(2015) \\
\text { Trigueros and Sendra (2015) }\end{array}$ & Tulum & $3.4-4.5$ & Gürsoy et al. (2003) \\
\hline Keffir & 4.6 & $\begin{array}{l}\text { Paszczyk and Rafalowski } \\
\text { (2015) }\end{array}$ & Teneke Tulum & $2.7-5.4$ & Gürsoy et al. (2003) \\
\hline Kaymak & 0.3 & $\begin{array}{l}\text { Okur and Guzel-Seydim } \\
\text { (2012) }\end{array}$ & Fresh Kashar & $0.01-5.4$ & Gürsoy et al. (2003) \\
\hline Long-life milks & & & Aged Kashar & $2.1-12.6$ & $\begin{array}{l}\text { Gürsoy et al. }(2003) \\
\text { Okur and Guzel-Seydim } \\
(2012)\end{array}$ \\
\hline UHT milk & 3.3 & $\begin{array}{l}\text { Paszczyk and Luczyńska } \\
(2020)\end{array}$ & $\begin{array}{l}\text { White pickeled } \\
\text { cheeses }\end{array}$ & $0.0-5.5$ & Gürsoy et al. (2003) \\
\hline High fat dairy products & & & Mild Cheddar & 1.9 & Mushtaq et al. (2010) \\
\hline Double cream & 3.7 & Mushtaq et al. (2010) & & & \\
\hline Butter & $0.9-11.3$ & $\begin{array}{l}\text { Chin } \text { et al. (1992) } \\
\text { Okur and Guzel-Seydim } \\
\text { (2012) Paszczyk } \text { et } \text { al. }(\mathbf{2 0 1 2 b})\end{array}$ & Processed cheese & $5.7-7.3$ & $\begin{array}{l}\text { Zhang et al. (2007) } \\
\text { Mushtaq et al. }(2010)\end{array}$ \\
\hline Frozen dairy products & & & Fresh goat cheese & 6.0 & Cossignani et al. (2014) \\
\hline Ice cream & $0.9-4.6$ & $\begin{array}{l}\text { Chin et al. (1992) } \\
\text { Mushtaq et al. }(2010)\end{array}$ & $\begin{array}{l}\text { Semi hard goat } \\
\text { cheese }\end{array}$ & 8.0 & Cossignani et al. (2014) \\
\hline
\end{tabular}

It was found that consumption of CLA-enriched food products may produce a modest loss in body fat in humans when given at a dose of $3.2 \mathrm{~g} /$ day (Whigham et al., 2007). De Almeida et al. (2014) proved that butter naturally enriched in cis-9, trans-11 CLA prevented hyperinsulinemia and increased both serum HDL cholesterol and triacylglycerol levels in rats. Davoodi et al. (2013) reviewed many reports over the years which suggested that CLA, as a component of milk fat exhibited some anticarcinogenic effects - against colorectal cancer (Liew et al., 1995), breast cancer (Zlatanoz et al. 2002; Keley et al., 2007), prostate cancer (Parodi, 2009). Virsangbhai et al. (2020) suggested that CLA is a potent fat-soluble antioxidant. Recommendations for CLA daily intake levels have to be established in the EU. However, recommended 3-6 g/day level intake could be suggested on the basis of potential health benefits (MacDonald, 2000).
The aim of the present paper was to provide an overview of the CLA-enriched dairy products, to discuss potential health benefits of CLA-enriched dairy products and to identify future directions for research as well as applications.

\section{FACTORS AFFECTING CLA-CONTENT IN MILK AND DAIRY PRODUCTS}

Fig. 2 represents the pathway of CLA from raw milk to dairy products in accordance with the applied process technology.

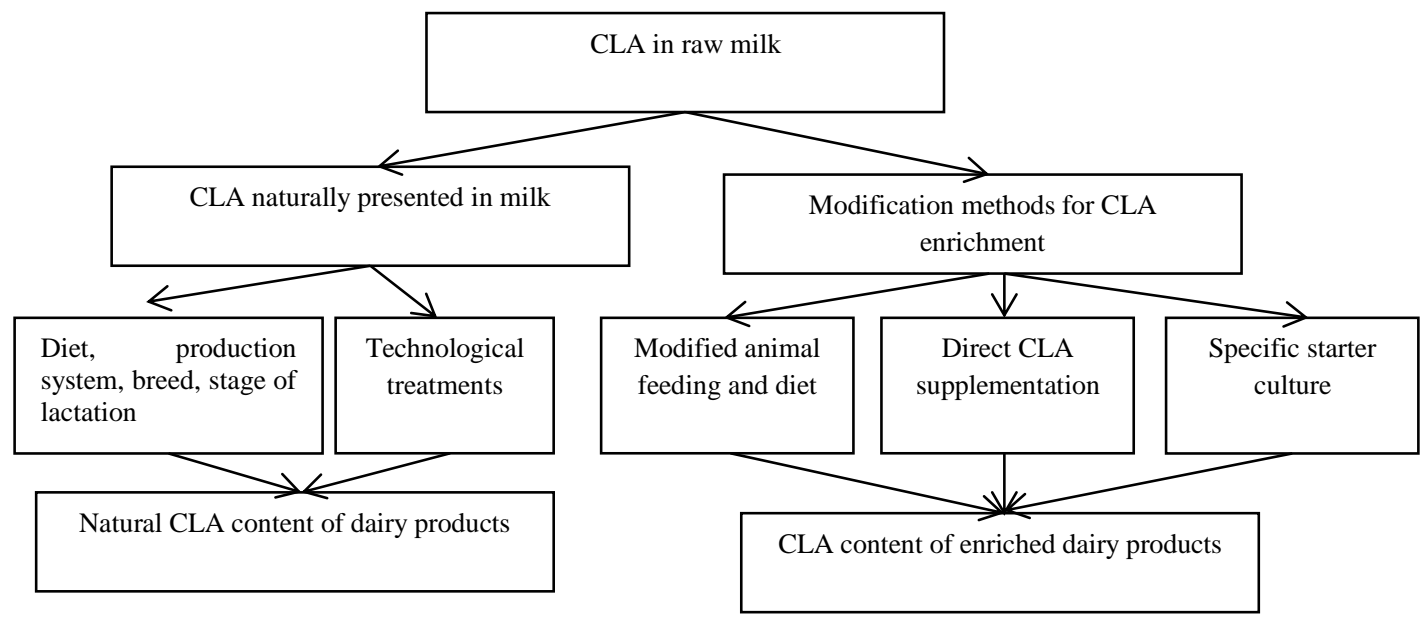

Figure 2 Factors affecting CLA-content in milk and dairy products 


\section{CLA NATURALLY PRESENTED IN MILK}

\section{Diet, production system, breed, stage of lactation}

Pasture based feeding diet had a beneficial effect on milk fatty acid profile (Stanton et al., 2018) in comparison to indoor feeding. The same tendency was confirmed by Ruiz et al. (2016). Kim et al. (2009) found $8.12 \mathrm{mg} \mathrm{CLA} / \mathrm{g}$ fat for cows fed on pastures and $6.76 \mathrm{mg} \mathrm{CLA} / \mathrm{g}$ fat for cows fed indoor. Cabiddu $\boldsymbol{e t}$ al. (2003) studied the influence of different pastures on milk composition, with particular reference to CLA and its precursors. Higher amount of CLA and its precursors in milk and cheese were found in the group Lolium rigidum + Medicago polymorpha + Chrysanthemum coronarium.

O'Callaghan et al. (2016b) investigated the effects of different feeding systems on milk quality and composition. They have found that the pasture feeding systems induced significantly higher concentrations of CLA content of milk compared with that of the total mixed ration diet (TMR) feeding system. This was confirmed by other authors who established that milk obtained from cows fed in the traditional system, especially in the summer season, contained $1.42 \%$ more CLA (Barlowska et al., 2012). Ruiz et al. (2016) compared animal feeding system utilized by the dairy farm and found higher CLA levels in raw milk based on grazing systems than housing systems using TMR diets. Prandini $\boldsymbol{e t}$ al. (2004) stated that cis-9, trans-11 CLA content was negatively correlated with the concentration of crude fiber.

The impact of lactation stage on milk fat fatty acid profile of grazing dairy cows was studied (Kirchnerová et al., 2013). They found that with the number of days of lactation a significant decrease in milk CLA content was established in relation to the amount of already produced milk, fat and protein. The rumenic acid content of Emmental cheese varied between $0.6 \%$ and $1.5 \%$ of total fatty acids according to the season and region of production, and appeared homogeneous through the cheese wheel (Chamba et al., 2006). According to Ruiz et al. (2016) average values of CLA were $1.72 \mathrm{~g} / 100 \mathrm{~g}$ of total fatty acids, in spring milk and $0.42 \mathrm{~g} / 100 \mathrm{~g}$ in summer milk and according to Kim et al. (2009) about $6.8 \mathrm{mg}$ CLA/g fat in spring and relatively low in midsummer and winter (about $4.3 \mathrm{mg}$ CLA/g fat). Seasonal variation was observed by Rutkowska and Adamska (2011) in the content of conjugated linoleic acid C18:2 cis-9, trans-11 (CLA) with significant content of $580 \mathrm{mg}$ CLA/100g of product on average (determined in butter samples produced in the summer and autumn season). Prandini et al. (2004) found higher cis-9, trans-11 CLA concentration in spring milks (14.53 $\mathrm{mg} / \mathrm{g}$ fat) and gradually decreased from summer to winter, when the lowest values were found $(9.20 \mathrm{mg} / \mathrm{g}$ fat $)$. In recent studies, mathematical models were created based on data of the CLA and fatty acid composition of dairy products in the purpose to predict the CLA content of other dairy products (Nunes and Torres, 2012).

Bonczar et al. (2016) studied the influence of three breeds on sweet cream. CLA prevailed in the milk fat produced by the cows of the Polish Holstein-Friesian breed, red-white variety. Mountain Grana Padano cheese contained more CLA than low-land hill Grana Padano and this fact was more pronounced when cheese was produced from summer milk in comparison with spring milk (Prandini $\boldsymbol{e} t$ al., 2009b).

Several authors have found that organic milk has a higher CLA content (Prandini et al., 2009a; Tudisco et al., 2010). Butler et al. (2011) suggested that organic or low-input dairy management was more likely to result in milk higher in beneficial isomers of CLA. This tendency was even more remarkable when producing fermented organic milks with significantly higher amounts of CLA than the same milk before fermentation (Florence et al., 2009). Grana Padano cheese was characterized by a higher CLA content when produced by organic farming system in comparison with the control sample produced by conventional system (Prandini et al., 2009a). The fat from the bio-yoghurts had the highest mean content of CLA (7.62 mg/g) (Paszczyk and Luczyńska, 2020). The analysis of the considered data showed that the natural content of CLA was influenced by a number of factors. Further investigaions could be done in order to predict more precisely the estimated natural CLA content according to the diet, applied production system, breed type and stage of lactation.

\section{Technological treatments}

Heat treatments and homogenization of milk caused oxidation of valuable anticancer CLA through exposure to high temperatures, high pressures, and reduction of fat globule size (Norgauer, 2005). Application of high temperature short time pasteurisation (HTST) resulted in a significant decrease of the cis-9, trans-11 isomer and other minor CLA isomers (Campbell et al., 2003). These results were found in milk that was fortified with CLA at very high doses $(30 \%)$ which resulted in a significant, but rather moderate loss of CLA (c.a. 10\% loss). Refrigerated storage of HTST milk decreased the cis-9, trans-11 isomer concentration after 3 weeks (Campbell et al., 2003). Campbell et al. (2003) found no differences in lipid oxidation between milks with or without added CLA even the fact that fortified HTST milks were supplemented with vitamin E and rosemary extract to prevent lipid oxidation. Ruiz et al. (2016) found that milk processing significantly affected the transferring of CLA from raw milk into dairy products (sweetened condensed milk and powdered milk). Shantha $\boldsymbol{e t}$ al.
(1995) found increased CLA concentration in salted butter (1.32 fold) in comparison with unsalted butter (1.27). They stated no changes in CLA content in processed dairy products such as low-fat yogurt, regular yogurt, low-fat and regular ice cream, sour cream or cheeses such as Mozzarella, Gouda and Cheddar. Storage did not affect CLA concentration in any products, suggesting that CLA is a stable component (Shantha et al., 1995). Dave et al. (2002) established no significant influence of milk processing (incorporation of milk powder and heat treatment at $85^{\circ} \mathrm{C}$ for $30 \mathrm{~min}$, fermentation with yogurt and probiotic bacteria and storage) on CLA-concentrations of probiotic CLAenriched yoghurts. Garcia-Lopez et al. (1994) analysed changes of CLA content in processed cheese during processing and found CLA to increase from $9.5 \mathrm{mg} / \mathrm{g}$ of fat in the raw ingredients to $10.7 \mathrm{mg} / \mathrm{g}$ of fat in the finished product without apparent changes in the isomer distribution. The culinary utilization and processing did not change the rumenic acid content of Emmental cheese (Chamba et al., 2006). Avilez and Meyer (2014) assessed the effect of processing fresh milk into milk powder and condensed milk. They found $1.35 \mathrm{~g}$ CLA/100 $\mathrm{g}$ of fatty acids in fresh milk and 1.45 and $0.93 \mathrm{~g} / 100 \mathrm{~g}$ fatty acids transferred to the milk powder and condensed respectively. As isomers, the cis-9, trans-11 had higher levels in the powdered milk than fresh milk in 7 months of the 10 months studied with values from 0.50 to $0.84 \mathrm{~g} / 100 \mathrm{~g}$ fatty acids. These data were confirmed by Ruiz et al. (2016) who found that sweetened condensed milk presented lower CLA values than raw and powdered milk. No differences were found in the profiles of fatty acids in the fats of milk, sweet cream, and cream, which confirmed their stability during the centrifugation and pasteurisation of milk as well as during the acidification with starter cultures (Bonczar et al., 2016). 7-month cheese aging showed higher CLA content than 4 months-aged cheeses, independently of the type of feeding (Kim et al., 2009) The same tendency was established for Swiss - type Kormoran cheeses which accumulated more CLA over 6-weeks of ripening (Paszczyk and Luczyńska, 2018). It was established that thermal processing applied in the manufacture of fermented milk on the stability of CLA diminished the quantity of polyunsaturated CLA in the product (Liutkevičius et al., 2009). It was concluded that aging is an essential factor to obtain higher amounts of conjugated linoleic acid (Okur and Guzel-Seydim, 2012). Zhang et al. (2007) observed no effect on CLA content in processed cheese food and processed cheese spread caused by mixing (reducing), homogenization and storage period, but heating at $90^{\circ} \mathrm{C}$ relative to $75^{\circ} \mathrm{C}$ significantly increased total CLA content in both cheeses Zengin et al. (2011) studied the influence of milk pasteurization (between 70 and $90^{\circ} \mathrm{C}$ for $5 \mathrm{~min}$ ) on its CLA-content in order to produce white pickled cheese and found no effect on CLA concentrations. CLA content in ghee prepared using indigenous method was higher as compared to that of a creamery method (Tyagi et al., 2015). Romno et al. (2008) found that ripening grade did not influence on the CLA concentration (the highest content was of cis-9, trans-11 isomer) of Provolone del Monaco cheese. The same fact was observed by Renes et al. (2019) in CLA-enriched sheep cheese. Prandini et al. (2011) suggested that the factors involved in the cheese making process generally did not affect the CLA content in milk fat because they found no statistically significant differences in CLA concentration when cheeses were produced from the same ruminant species but through different production technologies. Milk processing and cheese aging had a negative effect on CLA concentration in Peccorino cheese (Prandini et al. 2004). The obtained results demonstrated that the applied technological treatment influenced CLA content in milk and dairy products.

\section{MODIFICATION METHODS ENHANCING CLA-CONTENT IN DAIRY PRODUCTS}

\section{Diet modification}

Another possibility to enhance milk CLA content was to modify the animal's diet. Pesmen (2016) summarized the factors affecting CLA content enhancement of milk and dairy products and concluded that fish, sunflower, corn and canola oil had positive effects for this purpose. Oils were added into the diet in the form of protected oils, free oils, processed oilseeds or whole oilseeds (extruded, crushed, roasted or ground) (Virsangbhai et al., 2020). Gonzalez et al. (2003) altered the degree of unsaturation in milk fat by modifying the diets of Holstein cows in order to produce high-oleic and high-linoleic butter and ice cream. Cow and buffalo fed roughage based diet type one berseem (Trifolium alexandrinum) fodder along with wheat straw and type two concentrate mixtures and wheat straw (Tyagi et al., 2015). It was found that total CLA content in milk was higher in berseem fed groups of both the species. Jones et al. (2005) fed earlylactation Holstein British Friesian cows with a mixture $(45 \mathrm{~g} / \mathrm{kg}$ on dry matter basis) of fish oil and sunflower oil (1:2 wt/wt) during two consecutive weeks Control sample milk produced contained 0.54 in total CLA/100 g fat and milk enriched in CLA $4.68 \mathrm{~g}$, respectively. Dave et al. (2002) collected milk from cows fed four diets consisting of a control (C), $\mathrm{C}$ with $2 \%$ fish oil (FO), $\mathrm{C}$ with $1 \%$ each of fish oils and extruded soybeans (FOES), and $\mathrm{C}$ with $2 \%$ extruded soybeans (ES) in order two enhance milk CLA-content. They found that milk, yogurt mix and yogurt from cows fed with FO or FOES diets showed a 4-fold increase in the concentration of CLA. Dos Santos et al. (2020) analysed the fatty acid profile in butter from cows fed with sunflower seeds with or without 
lignosulfonate and proved that the use of diets with pelleted sunflower seeds was possible to obtain butter with a desirable nutritional value in dairy products with $23.74 \mathrm{mg} / \mathrm{g}$ total lipid rumenic acid content. Dairy cows were fed sunflower seeds and pasture in order to increase of conjugated linoleic acid and vaccenic acid in anhydrous milk fat using dry fractionation (Herrera-Meza et al., 2012). The use of linseeds was also applied in order to enrich in CLA ewe's milk (Luna et al., 2005). The supplementation of elephant grass-based-diets with soybean oil increased CLA content linearly as the level of soybean oil in the diet increased (Lopes et al., 2019). The butter produced from afternoon milk had a lower content of C16:0 and a higher content of cis-9 C18:1 ( P < 0.05). Soybean oil and, to a small extent, the selective segregation of milk obtained from afternoon milking sessions are strategies that can be used to improve the fatty acid composition of butterfat. Different approaches can be applied in order to increase CLA in milk and dairy products. New sources can be used to achieve even higher CLA content.

\section{Direct supplementation}

Campbell et al. (2003) enhanced CLA in dairy products by direct addition of triglyceride oil (Clarinol ${ }^{\mathrm{TM}}$ G-80 1 and 2\%) into skim milk followed by HTST pasteurization and homogenization. Rodríguez-Alcalá and Fontecha (2007) added CLA oil supplement (Tonalin-80 such that the consumer received $2.4 \mathrm{~g} / \mathrm{d}$ of CLA by consuming 2 servings of fortified fresh dairy products with predominant isomers C18:2 cis-9, trans-11 CLA and C18:2 cis-10, trans-12 CLA, in a similar ratio, which ranged from 0.97 to 1.05. The same supplement (microcapsules powder - Tonalin $₫ 60 \mathrm{WDP}$, and oily preparation - Tonalin ${ }^{\circledR T G ~} 80$ ) was applied by Liutkevičius et al. (2009) in order to enrich in CLA fermented milks. Virsangbhai et al. (2020) reported the use of Safflorin ${ }^{\mathrm{TM}}$ (a mixture of cis-9, trans-11 and trans-10, cis-12 isomers of octadecadienoic acid in a 40:60 ratio) for CLA enrichment. Zhuang et al. (2018) prepared milk protein-based conjugated linoleic acid microcapsules and investigated the effect of casein micellar structure on their stability. The authors found adverse effects on the casein micellar structure which suggested a modification of casein micelles in order to improve the efficiency and chemical stability of such microcapsules.

\section{Addition of specific starter culture}

The addition of specific starter culture with or without specific substrate addition can be considered as a promising possibility to increase CLA levels in dairy products. The fermentation using microorganisms having linoleate isomerase activity was employed as a promisig technological alternative for the manufacture of fermented milk products with high content of CLA (Gutiérrez, 2016). Van Nieuwenhove et al. (2007a) investigated the influence of bacteria used as adjunct culture (Lactobacillus casei, Lactobacillus rhamnosus, Bifidobacterium bifidum and Streptococcus thermophilus) and the sunflower oil addition (to a final concentration of $200 \mu \mathrm{g} / \mathrm{ml}$ of linoleic acid) on the CLA content in buffalo cheese. They have found that only Streptococcus thermophilus strain did not increase the CLA content in fresh cheese. Bzducha and Obiedziński (2007) determined the influence of two probiotic Lactobacillus strains on the CLA content in model ripening cheeses. They found no significant changes in CLA content during the eight weeks of ripening at the storage temperature of $6^{\circ} \mathrm{C}$. Das et al. (2005) investigated the effect of yeast and bacterial and yeast adjuncts (three strains of Propionibacterium freudenreichii ssp. shermanii, Lactobacillus fermentum, Lactobacillus rhamnosus, Geotrichum candidum and Yarrowia lipolytica) on the CLA content and flavour of a washedcurd, dry-salted cheese. CLA levels remained unchanged over 4 months of ripening, but the addition of linoleic acid-rich safflower oil to the cheese curd increased the concentration of free linoleic acid generated in the cheese but the total CLA content did not change. The CLA contents were significantly higher in fermented milks showing shorter fermentation times demonstrated by Streptococcus thermophilus TA040-Bifidobacterium animalis ssp. lactis HN019 and BB12 in comparison with co-cultures of Streptococcus thermophilus TA040Bifidobacterium animalis ssp. lactis BL04 or B94 and Streptococcus thermophilus TA040-Lactobacillus delbrueckii ssp. bulgaricus LB340 (Florence et al., 2009). Pickle white cheeses were produced from whole milk with five different probiotic cultures (Enterococcus faecium, Lactobacillus paracasei, Bifidobacterium longum, Bifidobacterium bifidum and Lactobacillus acidophilus) (Gursoy et al., 2012). CLA-content of cheeses ranged from 3.52 to $3.92 \mathrm{mg} / \mathrm{g}$ and probiotic differences and storage process had not affected the CLA contents of the samples statistically (Gursoy $\boldsymbol{e t}$ al., 2012). A study demonstrated that the type of applied starter culture (Ceska-star Y508 culture) and storage time affected the content of CLA in fermented milk drinks (Paszczyk et al., 2016). The mean content of CLA in fresh drinks reached $3.60 \mathrm{mg} / \mathrm{g}$ fat, after 6 days $3.85 \mathrm{~g} / \mathrm{g}$ fat and after 13 day storage $3.89 \mathrm{mg} / \mathrm{g}$, respectively. Renes et al. (2019) achieved 1.19 times higher CLA content in sheep cheese because the addition of autochthonous CLA-producing Lactobacillus plantarum TAUL 1588 and Lactobacillus casei ssp. casei SS 1644 strains.

\section{DAIRY PRODUCTS ENRICHED IN CLA}

Bell and Kennelly (2011) summarized the potential of "designer milk" for the production of dairy products. According to Meraz-Torres and HernandezSanchez (2012) all dairy products were a source of CLA and can be considered as functional foods. CLA-enriched fresh, ripened and other dairy products were developed in order to enhance their nutritional and biological values. The need, the interest and the possibilities to produce dairy products from CLA-enriched milk are reviewed below.

\section{CLA-enriched fresh dairy products}

The effects of added conjugated linoleic acid (CLA) (1 and 2\% in the form of triglyceride oil) on the sensory, chemical, and physical characteristics of $2 \%$ total fat fluid milk were studied by Campbell et al. (2003). They established lower consumer acceptability for CLA-fortified milks compared to control milks, but the addition of chocolate flavour increased acceptability. Similar results were obtained by Jones et al. (2005) for CLA-enriched ultra-high temperature (UHT) treated milk, which sensory profile differed slightly from those of the control sample. Although the sensory profiles of the CLA-enriched milk and fresh cheese differed from those of the control product with respect to some attributes, the overall impression and flavour did not differ. Rodríguez-Alcalá and Fontecha (2007) evaluated the changes of CLA isomers composition in fresh dairy products (milk, fermented milk, yoghurt, fresh cheese, milk-juice blend) after processing and storage. They detected a significant decrease of total CLA in fresh cheese samples after 10 weeks of refrigerated storage, but not in CLA isomers C18:2 cis-9, trans-11 and C18:2 trans-10, cis-12. In the same research, the disappearance of some of the minor CLA isomers and a significant increase of C18:2 trans, trans isomers from cis, trans; trans, cis; and cis, cis in fermented milk, yogurt, and milk-juice blend were established. Gutiérrez (2016) revised the effects of technological treatments on CLA content variations in milk and fermented milks. Some substrates (maltodextrine and fructooligosaccharides) in combination with probiotic starter cultures showed to be an effective method for enhancing the concentration of CLA in fermented milks (Akalın et al., 2007). In contrary, it has been reported that the addition of sucrose, fructose and lactose $(60 \mathrm{~g} / \mathrm{L})$ led to an inhibition of the CLA production in yogurts elaborated using Lactobacillus acidophilus and Lactobacillus delbrueckii ssp. bulgaricus (Lin, 2000).

According to Van Nieuwenhove et al. (2007a) sunflower oil supplementation increased CLA concentrations in fresh cheeses in combination with appropriate adjunct cultures (Lactobacillus casei, Lactobacillus rhamnosus, Biffidobacterium biffidum). CLA was found to be significantly positively correlated with transvaccenic acid and negatively correlated with linoleic acid in fermented milks (Florence et al., 2009). Other authors observed that the higher the linoleic acid in the sample the higher concentration of conjugated linoleic acid (Okur and Guzel-Seydim, 2012). A positive correlation between the CLA and linoleic acid contents of Lactobacillus paracasei and Lactobacillus acidophilus cheeses was confirmed by Gursoy et al. (2012). Addition of oily CLA preparation slightly increased the quantity of the separated whey in fermented milks enriched in CLA and decreased the viscosity of the product (Liutkevičius et al., 2009). According to the same authors, the addition of CLA in microcapsules powder form caused better sineretical properties and the increase in viscosity of the product. They established that the addition of CLA $(0.25-0.75 \%)$ independent of its form had no significant influence on the odour, taste, textural properties and acceptability of the fermented milk

\section{CLA-enriched ripened dairy products}

Various specific health effects due to a consumption of cheese enriched in CLA have been proven. Murru et al. (2018) demonstrated that CLA-enriched cheeses, consumed for different periods of time, were an alternative nutritional source of omega-3 highly unsaturated fatty acids in humans. However, CLA-enhanced cheese demonstrated less firmness as compared to the control sample (Jones $\boldsymbol{e t}$ al., 2005).

The effects of pasture-based versus indoor TMR feeding systems on the chemical composition, quality characteristics, and sensory properties of full-fat Cheddar cheeses were investigated (O'Callaghan et al., 2017). Pasture-based feeding systems demonstrated a greater 2-fold increase in the concentration of the bioactive conjugated linoleic acid C18:2 cis-9, trans-11, in comparison with TMR-derived cheeses. This alteration in cheese fatty acid profile resulted in reduced hardness scores at room temperature but enhanced nutritional quality. Mele et al. (2011) characterized the composition and the oxidative stability of lipids from Pecorino cheese enriched with CLA (cis-9, trans-11 CLA, trans-11 C18:1 and alpha-linolenic acid was increased by $290 \%, 197 \%$ and $250 \%$, respectively), obtained by supplementing the diet of dairy ewes with extruded linseed. Van Nieuwenhove et al. (2007a) stated that ripening and sunflower oil supplementation showed a positive influence on the CLA content in ripened buffalo cheese samples produced by adjunct starter cultures (Lactobacillus casei, Lactobacillus rhamnosus, Biffidobacterium biffidum and Streptococcus thermophilus). Texture and colour were similar in both types of cheese. Luna et 
al. (2005) found that sensory characteristics of cheeses made with CLA-enriched milk (ewes fed with linseed supplements) did not substantially differ from those made with non-supplemented ewes' milk. CLA total content and isomer profile did not change during ripening. CLA-enriched sheep cheese had no appreciable changes on sensory characteristics in comparison with the control sample (Renes et al., 2019).

\section{Other CLA-enriched dairy products}

A recent study evaluated the effects of three widely practiced cows feeding systems in the United States, Europe, and Southern Hemisphere regions on the characteristics, quality, and consumer perception of sweet cream butter (O'Callaghan et al., 2016a). It was found a significantly higher concentration of conjugated linoleic acid (cis-9, trans-11) in butter produced from pasture-derived milks than TMR butter. They observed alterations in the fatty acid composition of butter contributed to significant differences in textural and thermal properties of the butter. Jones et al. (2005) also found less firm CLA-enhanced butter as compared to control product. Gonzalez et al. (2003) established that the solid fat index of high-oleic and high-linoleic milkfat in CLA-enriched butter was lower than the control.

CLA content of fortified milk powder was affected by refrigerated storage and thermal treatment (Rodríguez-Alcalá and Fontecha, 2007).

Few researches about ice cream CLA-fortification were published (Gonzalez $\boldsymbol{e} t$ al., 2003). They found that control ice cream mixture had higher viscosity compared with high-oleic and high-linoleic, but the firmness of all ice creams was similar when measured between -17 and $-13^{\circ} \mathrm{C}$. Enriched anhydrous milk fat (AMF) and fractions (at $25,20,15,10,5,0$ and $-5^{\circ} \mathrm{C}$ ) showed CLA increase by $31 \%$ in enriched AMF and $59 \%$ after fractionation (liquid fraction at $0{ }^{\circ} \mathrm{C}$ ) when compared to control samples (Herrera-Meza et al., 2012). According to the authors this new technology, called "dry fractionation", was an inexpensive chemical-free process that may be used to produce CLA-rich products such as butter, cream, cookies and bread, in a way that would not be possible with conventional dairy processing equipment.

Figure 3 represents some examples of CLA-enriched dairy products

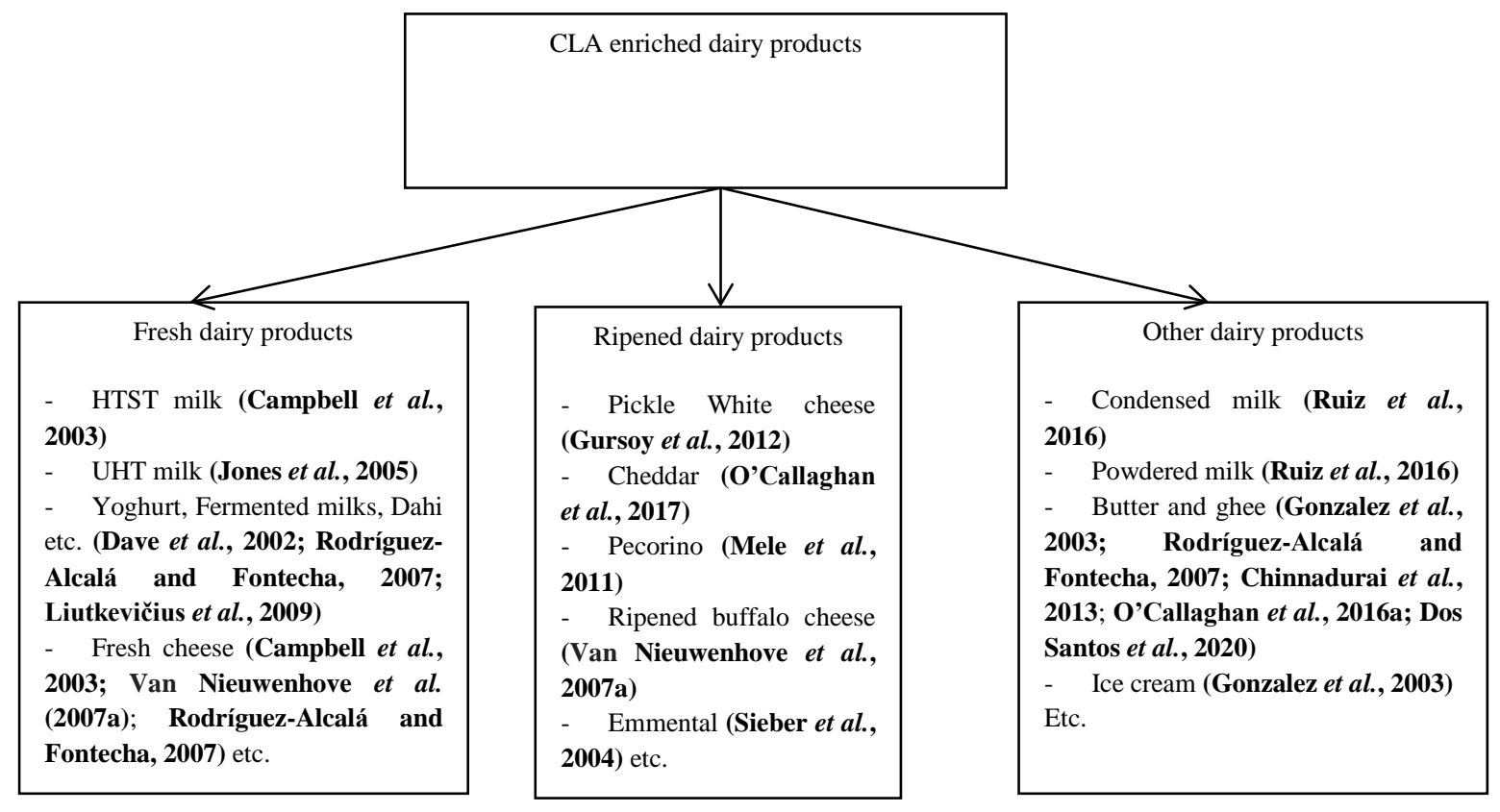

Figure 3 Examples of CLA-enriched dairy products

\section{POTENTIAL HEALTH BENEFITS OF CLA-ENRICHED DAIRY PRODUCTS}

Gama et al. (2015) findings suggested that dairy products enriched in cis-9, trans-11 CLA may be useful in the treatment of and respectively correlated significantly with memory enhancement. Biglu et al. (2017) demonstrated by meta-analysis that milk enrichment with CLA was an effective action agains cancer. Limong et al. (2018) studied the impact of cheese rich in CLA on LDLCholesterol by dietary intervention in older people. They found that participants who consumed Pecorino cheese,rich in CLA did not register an increase in lipid levels. Pintus et al. (2013) proved that sheep cheese naturally enriched in $\alpha$ linolenic, conjugated linoleic and vaccenic acids improved the lipid profile and reduced anandamide in the plasma of hypercholesterolaemic subjects. Mele $\boldsymbol{e t} \boldsymbol{a l}$. (2011) established that changes in lipid composition did not increase the amount of cholesterol oxidation products and slightly increased the thiobarbituric acidreactive substances. This suggestion demonstrated that CLA-enriched cheese did not represent any potential risk related to increased intake of lipid oxidation products. Lordan and Zabetakis (2017) discussed the anti-inflammatory properties of CLA-enriched milk, yogurt, and cheese. Barros et al. (2017) evaluated the effect of diet CLA-enriched butter on intestinal damage and inflammatory response and stated that this product exacerbated the 5-FU-induced intestinal damage. Penedo et al. (2013) stated that intake of butter naturally enriched with cis-9, trans-11 conjugated linoleic acid reduced systemic inflammatory mediators in healthy young adults. Chinnadurai et al. (2013) proved that high CLA-enriched ghee/clarified butter $(19.54 \mathrm{mg} / \mathrm{g}$ fat $)$ increased the antioxidant and antiatherogenic potency in female Wistar rats. Ritzenthaler et al. (2005) proved that consumption of conjugated linoleic acid (CLA) from CLA-enriched cheese did not alter milk fat or immunity in lactating women. According to Rodríguez-Alcalá et al. (2013) CLA-enriched milk powder reversed hypercholesterolemic risk factors in hamsters. Recent research demonstrated that the dietary cis-9, trans-11-conjugated linoleic acid enriched from butter reduced breast cancer progression in vivo (Zeng et al., 2020) Stefanson et al. (2014) have found that feeding butter with elevated content of trans-10, cis-12 conjugated linoleic acid to lean rats did not impair glucose tolerance or muscle insulin response.

\section{CONCLUSION}

The most recent data concerning CLA-enriched dairy products were presented in this review. While there are a lot of data for the possibilities to enrich dairy products with CLA, this area needs further investigations on some issues. Further studies are needed to determine the most appropriate group of dairy products for CLA enrichment. Additional studies should be performed to determine new antioxidants, their respective concentrations and methods for prevention of CLA oxidation. CLA content variations of different dairy products enriched with CLA remain still not completely clear. It is still unknown why some strains of microorganisms produce greater amounts of CLA than others. The influence of the substrate in CLA formation must be further clarified. There is a need of more recent findings in the physiological effects of nutritionally desirable CLA and its isomers, presented in dairy enriched products, on human organism. There is a need of improved knowledge about the improvement of milk fat composition through various factors as feeding regime, production system, breed, or stage of lactation. All of these concerns are in correspondence with the requirements of the growing market of functional foods.

\section{REFERENCES}

Ahmad, N., Kamran Khan, M., Imran, M., Nadeem Suleman, M., \& Afzal, S. (2019). Bovine Feed Manipulation, Enhancement of Conjugated Linoleic Acid and Its Bioavailability. Bovine Science - A Key to Sustainable Development. http://dx.doi.org/10.5772/intechopen.79306 
Akalın, A. S., Tokuşoğlu, Ö., Gönç, S., \& Aycan, Ş. (2007). Occurrence of conjugated linoleic acid in probiotic yoghurts supplemented with fructooligosaccharide. International Dairy Journal, 17(9), 1089-1095. http://dx.doi.org/10.1016/j.idairyj.2007.02.005

Avilez R, J. P., \& Meyer R, J. (2014). Transferencia del ácido linoleico conjugado (CLA) de la leche cruda a leche en polvo y condensada. Revista Chilena de Nutrición, 41(4), 420-424. http://dx.doi.org/10.4067/s071775182014000400011

Barłowska, J., Litwińczuk, Z., Brodziak, A., \& Chabuz, W. (2012). Effect of the production season on nutritional value and technological suitability of milk obtained from intensive (TMR) and traditional feeding system of cows. Journal of Microbiology, Biotechnology and Food Sciences, 1(5), 1205-1220.

Barros, P. A. V. de, Generoso, S. de V., Andrade, M. E. R., da Gama, M. A. S., Lopes, F. C. F., de Sales e Souza, É. L., ... Cardoso, V. N. (2016). Effect of Conjugated Linoleic Acid-enriched Butter After 24 hours of Intestinal Mucositis Induction. Nutrition and Cancer, 69(1), 168-175. http://dx.doi.org/10.1080/01635581.2016.1225100

Bell, J. A., \& Kennelly, J. J. (2001). Conjugated linoleic acid enriched milk: A designer milk with potential. Advances in Dairy Technology, 13, 213-228

Bhat, Z. F., \& Bhat, H. (2011). Milk and Dairy Products as Functional Foods: A Review. International Journal of Dairy Science, 6(1), 1-12. http://dx.doi.org/10.3923/ijds.2011.1.12

Biglu, M.-H., Janmohammadi, H., \& Mirzapour, L. (2017). Scientific Advances of Milk Enrichment with Conjugated Linoleic Acid to Produce Anti-Cancer Milk. Iranian Journal of Cancer Prevention, In Press(In Press). http://dx.doi.org/10.17795/ijcp-5868

Bonczar, G., Pustkowiak, H., Domagała, J., Najgebauer-Lejko, D., Sady, M., Walczycka, M., \& Wszołek, M. (2016). Content of cholesterol and fatty acid profile in sweet cream and cream made from milk produced by cows of three different breeds. Zywnosc Nauka Technologia Jakosc/Food Science Technology Quality, 105(2), 81-94. http://dx.doi.org/10.15193/zntj/2016/105/117

Butler, G., Nielsen, J. H., Larsen, M. K., Rehberger, B., Stergiadis, S., Canever, A., \& Leifert, C. (2011). The effects of dairy management and processing on quality characteristics of milk and dairy products. NJAS - Wageningen Journal of Life Sciences, 58(3-4), 97-102. http://dx.doi.org/10.1016/j.njas.2011.04.002

Bzducha, A., \& Obiedziński, M. W. (2007). Influence of two probiotic Lactobacillus strains on CLA content in model ripening cheeses. Polish Journal of Food and Nutrition Sciences, 57(4A), 65-69.

Cabiddu, A., Decandia, M., Molle, G., Pinna, G., Addis, M., Spada, S., Pirisi, A. \& Piredda, G. (2003). Effect of different pastures on CLA content in milk and sheep cheese. Italian Journal of Animal Science, 2(1), 518-520. https://doi.org/10.4081/ijas.2003.11676062

Campbell, W., Drake, M. A., \& Larick, D. K. (2003). The Impact of Fortification with Conjugated Linoleic Acid (CLA) on the Quality of Fluid Milk. Journal of Dairy Science, 86(1), 43-51. http://dx.doi.org/10.3168/jds.s0022-0302(03)73582

Chamba, J., Chardigny, J. M., Gnädig, S., Perreard, E., Chappaz, S., Rickert, R., Steinhart, H., \& Sébédio, J. L. (2006). Conjugated linoleic acid (CLA) content of French Emmental cheese : effect of the season, region of production, processing and culinary preparation. Lait, 86, 461-467. http://dx.doi.org/10.1051/lait:2006019

Chin, S. F., Liu, W., Storkson, J. M., Ha, Y. L., \& Pariza, M. W. (1992). Dietary sources of conjugated dienoic isomers of linoleic acid, a newly recognized class of anticarcinogens. Journal of Food Composition and Analysis, 5(3), 185-197. http://dx.doi.org/10.1016/0889-1575(92)90037-k

Chinnadurai, K., Kanwal, H., Tyagi, A., Stanton, C., \& Ross, P. (2013). High conjugated linoleic acid enriched ghee (clarified butter) increases the antioxidant and antiatherogenic potency in female Wistar rats. Lipids in Health and Disease, 12(1), 121. http://dx.doi.org/10.1186/1476-511x-12-121

Collomb, M., Schmid, A., Sieber, R., Wechsler, D., \& Ryhänen, E.-L. (2006) Conjugated linoleic acids in milk fat: Variation and physiological effects International Dairy Journal, 16(11), 1347-1361. http://dx.doi.org/10.1016/j.idairyj.2006.06.021

Cossignani, L., Giua, L., Urbani, E., Simonetti, M. S., \& Blasi, F. (2014). Fatty acid composition and CLA content in goat milk and cheese samples from Umbrian market. European Food Research and Technology, 239(6), 905-911. http://dx.doi.org/10.1007/s00217-014-2287-8

Das, S., Holland, R., Crow, V. L., Bennett, R. J., \& Manderson, G. J. (2005). Effect of yeast and bacterial adjuncts on the CLA content and flavour of a washed-curd, dry-salted cheese. International Dairy Journal, 15(6-9), 807-815. http://dx.doi.org/10.1016/j.idairyj.2004.08.023

Dave, R., Ramaswamy, N., Baer, \& R.J. (2002). Changes in fatty acid composition during yogurt processing and their effects on yogurt and probiotic bacteria in milk procured from cows fed different diets. Australian Journal of Dairy Technology, 57(3), 197-202.

Davoodi, H., Esmaeili, S., \& Mortazavian, A. M. (2013). Effects of Milk and Milk Products Consumption on Cancer: A Review. Comprehensive Reviews in Food Science and Food Safety, 12(3), 249-264. http://dx.doi.org/10.1111/1541$\underline{4337.12011}$
De Almeida, M. M., Luquetti, S. C. P. D., Sabarense, C. M., Corrêa, J. O. do A., dos Reis, L. G., Conceição, E. P. S. da, ... Garcia, R. M. G. (2014). Butter naturally enriched in cis-9, trans-11 CLA prevents hyperinsulinemia and increases both serum HDL cholesterol and triacylglycerol levels in rats. Lipids in Health and Disease, 13(1). http://dx.doi.org/10.1186/1476-511x-13-200

Dos Santos, W. B. R., dos Santos, G. T., Kazama, D. C. da S., Valente, T. N. P., Monteiro, J. P., De Marchi, F. E., ... Ribeiro, J. C. (2020). Fatty Acid Profile in Butter from Cows Fed with Sunflower Seeds with or Without Lignosulfonate. American Journal of Animal and Veterinary Sciences, 15(2), 153-162. http://dx.doi.org/10.3844/ajavsp.2020.153.162

Florence, A. C. R., da Silva, R. C., do Espírito Santo, A. P., Gioielli, L. A., Tamime, A. Y., \& de Oliveira, M. N. (2009). Increased CLA content in organic milk fermented by bifidobacteria or yoghurt cultures. Dairy Science and Technology, 89(6), 541-553. http://dx.doi.org/10.1051/dst/2009030

Gama, M. A. S., Raposo, N. R. B., Mury, F. B., Lopes, F. C. F., Dias-Neto, E. Talib, L. L., \& Gattaz, W. F. (2015). Conjugated linoleic acid-enriched butter improved memory and up-regulated phospholipase A2 encoding-genes in rat brain tissue. Journal of Neural Transmission, 122(10), 1371-1380. http://dx.doi.org/10.1007/s00702-015-1401-9

Garcia-Lopez, S., Echeverria, E., Tsui, I., \& Balch, B. (1994). Changes in the content of conjugated linoleic acid (CLA) in processed cheese during processing. Food Research International, 27(1), 61-64. http://dx.doi.org/10.1016/09639969(94)90178-3

Gonzalez, S., Duncan, S. E., O'Keefe, S. F., Sumner, S. S., \& Herbein, J. H. (2003). Oxidation and Textural Characteristics of Butter and Ice Cream with Modified Fatty Acid Profiles. Journal of Dairy Science, 86(1), 70-77. http://dx.doi.org/10.3168/jds.s0022-0302(03)73585-1

Gursoy, O., Seckin, A. K., Kinik, O., \& Karaman, A. D. (2011). The effect of using different probiotic cultures on conjugated linoleic acid (CLA) concentration and fatty acid composition of white pickle cheese. International Journal of Food Sciences and Nutrition, 63(5), 610-615. http://dx.doi.org/10.3109/09637486.2011.643295

Gürsoy, O., Seçkin, A. K., Kinik, Ö., \& Metin, M. (2003). Conjugated linoleic acid (CLA) content of most popular Turkish hard and soft cheeses. Milchwissenschaft, 58(11-12), 622-623.

Gutiérrez, L. F. (2016). Conjugated linoleic acid in milk and fermented milks: variation and effects of the technological processes. Revista Vitae, 23(2), 134 145. http://dx.doi.org/10.17533/udea.vitae.v23n2a06

Hernandez-, H., \& Meraz-Torr, L. S. (2012). Conjugated Linoleic Acid in Dairy Products: A Review. American Journal of Food Technology, 7(4), 176-179. http://dx.doi.org/10.3923/ajft.2012.176.179

Hernandez-, H., \& Meraz-Torr, L. S. (2012). Conjugated Linoleic Acid in Dairy Products: A Review. American Journal of Food Technology, 7(4), 176-179. http://dx.doi.org/10.3923/ajft.2012.176.179

Herrera-Meza, S., Mendoza-López, R., Jácome-Sosa, M., Proctor, S., Angulo, O., Silva-Hernández, E., \& Oliart-Ros, R. (2012). Increase of conjugated linoleic acid and vaccenic acid in anhydrous milk fat using dry fractionation and its effect on the atherogenic index. Interciencia, 37(7), 528-533.

Jones, E. L., Shingfield, K. J., Kohen, C., Jones, A. K., Lupoli, B., Grandison, A S., ... Yaqoob, P. (2005). Chemical, Physical, and Sensory Properties of Dairy Products Enriched with Conjugated Linoleic Acid. Journal of Dairy Science, 88(8), 2923-2937. http://dx.doi.org/10.3168/jds.s0022-0302(05)72973-8

Kelley, N. S., Hubbard, N. E., \& Erickson, K. L. (2007). Conjugated Linoleic Acid Isomers and Cancer. The Journal of Nutrition, 137(12), 2599-2607. http://dx.doi.org/10.1093/jn/137.12.2599

Kim, J. H., Kwon, O.-J., Choi, N.-J., Oh, S. J., Jeong, H.-Y., Song, M.-K., Kim, Y. J. (2009). Variations in Conjugated Linoleic Acid (CLA) Content of Processed Cheese by Lactation Time, Feeding Regimen, and Ripening. Journal of Agricultural and Food Chemistry, 57(8), 3235-3239. http://dx.doi.org/10.1021/jf803838u

Kirchnerová, K., Foltys, V., \& Jiř́ Špička, J. (2012). Milk fat fatty acids in relation to milk production and quality. Journal of Microbiology, Biotechnology and Food Sciences, 1, 1052-1064.

Kirchnerová, K., Foltys, V., \& Špicka, J. (2013). Impact of lactation stage ` on milk fat fatty acids profile in grazing dairy cows, Journal of Microbiology. Biotechnology and Food Sciences, 2, 1164-1174.

Liew, C., Schut, H. A. ., Chin, S. F., Pariza, M. W., \& Dashwood, R. H. (1995) Protection of conjugated linoleic acids against 2-amino-3-methylimidazo[4,5f]quinoline-induced colon carcinogenesis in the F344 rat: a study of inhibitory mechanisms. Carcinogenesis, 16(12), 3037-3043. http://dx.doi.org/10.1093/carcin/16.12.3037

Limongi, F., Noale, M., Marseglia, A., Gesmundo, A., Mele, M., Banni, S., .. Maggi, S. (2017). Impact of Cheese Rich in Conjugated Linoleic Acid on Low Density Lipoproteins Cholesterol: Dietary Intervention in Older People (CLADIS Study). Journal of Food and Nutrition Research, 6(1), 1-7. http://dx.doi.org/10.12691/jfnr-6-1-1

Lin, T. Y. (2000). Conjugated linoleic acid concentration as affected by lactic cultures and additives. Food Chemistry, 69(1), 27-31. http://dx.doi.org/10.1016/s0308-8146(99)00218-6 
Liutkevičius, A., Kulikauskiene, M., Narkevičius, R., Speičiene, V., Mieželiene, A., \& Alenčikiene, G. (2009). Properties of fermented milk enriched by conjugated linoleic acid and probiotics and peculiarities of technology. Veterinarija ir Zootechnika, 45(67), 33-40.

Lopes, F. C. F., Ribeiro, C. G. S., Rodriguez, N. M., Gama, M. A. S. da, Morenz, M. J. F., Antoniassi, R., \& Bizzo, H. R. (2019). Butter fatty acid composition as a function of soybean oil supplementation and time of milking, and performance of Holstein x Gyr cows fed with chopped elephant grass-based diets. Semina: Ciências Agrárias, 40(5), 2027-2044. http://dx.doi.org/10.5433/16790359.2019v40n5p2025

Lordan, R., \& Zabetakis, I. (2017). Invited review: The anti-inflammatory properties of dairy lipids. Journal of Dairy Science, 100(6), 4197-4212. http://dx.doi.org/10.3168/jds.2016-12224

Luna, P., Fontecha, J., Juárez, M., \& de la Fuente, M. A. (2005). Changes in the milk and cheese fat composition of ewes fed commercial supplements containing linseed with special reference to the CLA content and isomer composition. Lipids, 40(5), 445-454. http://dx.doi.org/10.1007/s11745-005-1403-3

MacDonald, H. (2000). Conjugated linoleic acid and disease prevention: a review of current knowledge. Journal of the American College of Nutrition, 19(2), 111585.

Markiewicz-Kęszycka, P., M., Czyżak-Runowska, G., Lipińska, P., \& Wójtowski, J. (2013). Fatty Acid Profile of Milk - A Review, Bulletin of the Veterinary Institute in Pulawy, 57(2), 135-139. http://dx.doi.org/10.2478/bvip2013-0026

Mele, M., Contarini, G., Cercaci, L., Serra, A., Buccioni, A., Povolo, M., Secchiari, P. (2011). Enrichment of Pecorino cheese with conjugated linoleic acid by feeding dairy ewes with extruded linseed: Effect on fatty acid and triglycerides composition and on oxidative stability. International Dairy Journal, 21(5), 365-372. http://dx.doi.org/10.1016/j.idairyj.2010.12.015

Murru, E., Carta, G., Cordeddu, L., Melis, M., Desogus, E., Ansar, H., ... Manca, C. (2018). Dietary Conjugated Linoleic Acid-Enriched Cheeses Influence the Levels of Circulating n-3 Highly Unsaturated Fatty Acids in Humans. International Journal of Molecular Sciences, 19(6), 1730 http://dx.doi.org/10.3390/ijms19061730

Mushtaq, S., Heather Mangiapane, E., \& Hunter, K. A. (2009). Estimation of cis9, trans-11 conjugated linoleic acid content in UK foods and assessment of dietary intake in a cohort of healthy adults. British Journal of Nutrition, 103(9), 1366-1374. http://dx.doi.org/10.1017/s000711450999328x

National Center for Biotechnology Information (2020). PubChem Compound Summary for CID 5282796, 9,11-Octadecadienoic acid. Retrieved August 17 2020 from https://pubchem.ncbi.nlm.nih.gov/compound/9_11-OCtadecadienoicacid.

Norgauer, C. (2005). Ecological study of the role of highly processed milk, meat and vegetable oil in prostate cancer causation. Boca Raton, Fla: UniversalPublishers.

Nunes, J. C., \& Torres, A. G. (2012). Predicting conjugated linoleic acid (CLA) composition in Brazilian dairy products by multiple regression analysis based models. Dairy Science \& Technology, 92(4), 399-413. http://dx.doi.org/10.1007/s13594-012-0073-6

O'Callaghan, T. F., Faulkner, H., McAuliffe, S., O’Sullivan, M. G., Hennessy, D., Dillon, P., ... Ross, R. P. (2016a). Quality characteristics, chemical composition, and sensory properties of butter from cows on pasture versus indoor feeding systems. Journal of Dairy Science, 99(12), 9441-9460. http://dx.doi.org/10.3168/jds.2016-11271

O'Callaghan, T. F., Hennessy, D., McAuliffe, S., Kilcawley, K. N., O’Donovan, M., Dillon, P., ... Stanton, C. (2016b). Effect of pasture versus indoor feeding systems on raw milk composition and quality over an entire lactation. Journal of Dairy Science, 99(12), 9424-9440. http://dx.doi.org/10.3168/jds.2016-10985

O'Callaghan, T. F., Mannion, D. T., Hennessy, D., McAuliffe, S., O'Sullivan, M. G., Leeuwendaal, N., ... Stanton, C. (2017). Effect of pasture versus indoor feeding systems on quality characteristics, nutritional composition, and sensory and volatile properties of full-fat Cheddar cheese. Journal of Dairy Science, 100(8), 6053-6073. http://dx.doi.org/10.3168/jds.2016-12508

Okur, Ö., \& Guzel-Seydim, Z. (2012). Determination of Fatty Acid Profiles Including Conjugated Linoleic Acids in Various Dairy Products. Asian Journal of Chemistry, 24(3,) 1104-1106.

Parodi, P. W. (2009). Dairy product consumption and the risk of prostate cancer. International Dairy Journal, 19(10), 551-565. http://dx.doi.org/10.1016/j.idairyj.2009.05.006

Paszczyk, B., \& Łuczyńska, J. (2018). Changes in the content of CLA and other trans isomers in the Kormoran cheese during six weeks of ripening. Polish Journal of Natural Sciences, 33(4), 579-589.

Paszczyk, B., \& Łuczyńska, J. (2020). Fatty acids profile, conjugated linoleic acid contents and fat quality in selected dairy products available on the Polish market. Czech Journal of Food Sciences, 38(2), 109-114. http://dx.doi.org/10.17221/341/2019-cjfs

Paszczyk, B., \& Rafałowski, R. (2015). Conjugated linoleic acid (cis9trans 11 C18:2, CLA) and trans isomers of C18:1 and C18:2 acids in yoghurts, kefirs and mold cheeses. Polish Journal of Natural Sciences, 30(1), 73-80.
Paszczyk, B., Borejszo, Z., \& Luczyńska, J. (2012a). Conjugated linoleic acid (CLA) and trans isomers of C18:1 and C18:2 acids in mould cheeses. Polish Journal of Natural Sciences, 27(1), 93-101.

Paszczyk, B., Brandt, W., \& Łuczyńska, J. (2016). Isomers of c18:1 and c18:2 Acids in Fresh and Stored Fermented Milks Produced with Selected Starter Cultures. Czech Journal of Food Sciences, 34(5), 391-396. http://dx.doi.org/10.17221/358/2015-cjfs

Paszczyk, B., Łuczyńska, J. Rafałowski, R., \& Borejszo, Z. (2012b). Content of cis9trans 11 c18:2 ACID (CLA) and trans isomers of C18:1 and C18:2 acids in butters. Polish Journal of Natural Sciences, 27(4), 491-500.

Penedo, L. A., Nunes, J. C., Gama, M. A. S., Leite, P. E. C., Quirico-Santos, T. F., \& Torres, A. G. (2013). Intake of butter naturally enriched with cis9,trans 11 conjugated linoleic acid reduces systemic inflammatory mediators in healthy young adults. The Journal of Nutritional Biochemistry, 24(12), 2144-2151. http://dx.doi.org/10.1016/j.jnutbio.2013.08.006

Peşmen, G. (2016). The Conjugated Linoleic Acid (CLA) Contents of Various Milk and Dairy Products and Affecting Factors. International Journal of Innovative Research in Science, Engineering and Technology. 5(12): 158-163.

Pintus, S., Murru, E., Carta, G., Cordeddu, L., Batetta, B., Accossu, S., ... Banni, S. (2012). Sheep cheese naturally enriched in $\alpha$-linolenic, conjugated linoleic and vaccenic acids improves the lipid profile and reduces anandamide in the plasma of hypercholesterolaemic subjects. British Journal of Nutrition, 109(8), 14531462. http://dx.doi.org/10.1017/s0007114512003224

Prandini, A., Conti, F., Diaz, D. E., \& Piva, G. (2004). Levels of conjugated linoleic acid (CLA) in ewe milk and Pecorino cheese: Effect of season, feed and cheese aging. Progress in Nutrition, 6(2), 115-121.

Prandini, A., Sigolo, S., \& Piva, G. (2009a). Conjugated linoleic acid (CLA) and fatty acid composition of milk, curd and Grana Padano cheese in conventional and organic farming systems. Journal of Dairy Research, 76(3), 278-282. http://dx.doi.org/10.1017/s0022029909004099

Prandini, A., Sigolo, S., \& Piva, G. (2011). A comparative study of fatty acid composition and CLA concentration in commercial cheeses. Journal of Food Composition and Analysis, 24(1), 55-61. http://dx.doi.org/10.1016/j.jfca.2010.04.004

Prandini, A., Sigolo, S., Cerioli, C., \& Piva, G. (2009b). Survey on conjugated linoleic acid (CLA) content and fatty acid composition of Grana Padano cheese produced in different seasons and areas. Italian Journal of Animal Science, 8(4), 531-540. http://dx.doi.org/10.4081/ijas.2009.531

Renes, E., Gómez-Cortés, P., de la Fuente, M. A., Linares, D. M., Tornadijo, M. E., \& Fresno, J. M. (2019). CLA-producing adjunct cultures improve the nutritional value of sheep cheese fat. Food Research International, 116, 819-826. http://dx.doi.org/10.1016/j.foodres.2018.09.016

Ritzenthaler, K. L., McGuire, M. K., McGuire, M. A., Shultz, T. D., Koepp, A E., Luedecke, L. O., ... Chew, B. P. (2005). Consumption of Conjugated Linoleic Acid (CLA) from CLA-Enriched Cheese Does Not Alter Milk Fat or Immunity in Lactating Women. The Journal of Nutrition, 135(3), 422-430. http://dx.doi.org/10.1093/jn/135.3.422

Rodríguez-Alcalá, L. M., \& Fontecha, J. (2007). Hot Topic: Fatty Acid and Conjugated Linoleic Acid (CLA) Isomer Composition of Commercial CLAFortified Dairy Products: Evaluation After Processing and Storage. Journal of Dairy Science, 90(5), 2083-2090. http://dx.doi.org/oi:10.3168/jds.2006-693

Rodríguez-Alcalá, L. M., Fontecha, J., de la Hoz, L., da Silva, V. S. N., Carvalho, J. E., \& Pacheco, M. T. B. (2013). CLA-enriched milk powder reverses hypercholesterolemic risk factors in hamsters. Food Research International, 51(1), 244-249. http://dx.doi.org/10.1016/j.foodres.2012.12.013

Romano, R., Borriello, I., Magaldi, C., Giordano, A., \& Musso, S.S. (2008) Ripening grade influence on fatty acids, $\omega-3$ and CLA of Provolone del Monaco cheese. Progress in Nutrition, 10(3), 165-173.

Ruiz, J. P. A., Alonzo, M. W., \& Pertíñez, M. D. (2016). Conjugated linoleic acid of dairy foods is affected by cows' feeding system and processing of milk. Scientia Agricola, 73(2), 103-108. http://dx.doi.org/10.1590/0103-9016-20150051

Ruiz, J. P. A., Alonzo, M. W., \& Pertíñez, M. D. (2016). Conjugated linoleic acid of dairy foods is affected by cows' feeding system and processing of milk. Scientia Agricola, 73(2), 103-108. http://dx.doi.org/10.1590/0103-9016-2015$\underline{0051}$

Rutkowska, J., \& Adamska, A. (2011). Fatty Acid Composition of Butter Originated from North-Eastern Region of Poland. Polish Journal of Food and Nutrition Sciences, 61(3), 187-193. http://dx.doi.org/10.2478/v10222-011-0020-

Shantha, N. C., Ram, L. N., O’Leary, J., Hicks, C. L., \& Decker, E. A. (1995). Conjugated Linoleic Acid Concentrations in Dairy Products as Affected by Processing and Storage. Journal of Food Science, 60(4), 695-697. http://dx.doi.org/10.1111/j.1365-2621.1995.tb06208.x

Sieber, R., Collomb, M., Aeschlimann, A., Jelen, P., \& Eyer, H. (2004). Impact of microbial cultures on conjugated linoleic acid in dairy products - a review. International Dairy Journal, 14(1), 1-15. http://dx.doi.org/10.1016/s0958$\underline{6946(03) 00151-1}$ 
Smit, L. A., Baylin, A., \& Campos, H. (2010). Conjugated linoleic acid in adipose tissue and risk of myocardial infarction. The American Journal of Clinical Nutrition, 92(1), 34-40. http://dx.doi.org/10.3945/ajcn.2010.29524

Song, M. K., \& Kennelly, J. J. (2002). Biosynthesis of Conjugated Linoleic Acid and Its Incorporation into Ruminant's Products. International Symposium on "Recent Advances in Animal Nutrition" held in New Delhi, India (September 22, 2002), 306-314

Stanton, C., Mills, S., Ryan, A., Di Gioia, D, Ross, R. P. (2018). Influence of pasture-feeding on milk and meat product quality. The Irish Agriculture and Food Development

https://www.egf2018.com/docs/day\%204/Session\%20IV\%20\%20Estuary\%20Suite\%20Plenary\%201400\%201500/1\%20-\%20Stanton.pdf

Stefanson, A., Hopkins, L. E., AlZahal, O., Ritchie, I. R., MacDonald, T., Wright, D. C., ... Dyck, D. J. (2014). Feeding butter with elevated content of trans-10, cis-12 conjugated linoleic acid to lean rats does not impair glucose tolerance or muscle insulin response. Lipids in Health and Disease, 13(1), 101 http://dx.doi.org/10.1186/1476-511x-13-101

Trigueros, L., \& Sendra, E. (2015). Fatty acid and conjugated linoleic acid (CLA) content in fermented milks as assessed by direct methylation. LWT - Food Science $\quad$ and 315-319. http://dx.doi.org/10.1016/j.lwt.2014.09.053

Tudisco, R., Cutrignelli, M. I., Calabrò, S., Piccolo, G., Bovera, F., Guglielmelli, A., ... Infascelli, F. (2010). Influence of organic systems on milk fatty acid profile and CLA in goats. Small Ruminant Research, 88(2-3), 151-155 http://dx.doi.org/10.1016/j.smallrumres.2009.12.023

Tyagi, A. K., Shandilya, U. K., Srivastava, A., Kale, V. R., \& Kewalramani, N. J. (2015). Fatty acids profile of milk and milk products in cow and buffalo fed roughage based diet. Indian Journal of Animal Sciences, 85(8), 889-896.

Van Nieuwenhove, C. P., Oliszewski, R., González, S. N., \& Pérez Chaia, A. B. (2007a). Influence of bacteria used as adjunct culture and sunflower oil addition on conjugated linoleic acid content in buffalo cheese. Food Research International, 40(5), 559-564 http://dx.doi.org/10.1016/j.foodres.2006.08.003

Van Nieuwenhove, C., Cano, P. G., Chaia, A. P., \& González, S. (2007b). chemical composition and fatty acid content of buffalo cheese from Northwest Argentina: effect on lipid composition of mice tissues. Journal of Food Lipids, 14(3), 232-243. http://10.1111/j.1745-4522.2007.00082.x

Virsangbhai, C. K., Goyal, A., Tanwar, B., \& Sihag, M. K. (2020). Potential Health Benefits of Conjugated Linoleic Acid: An Important Functional Dairy Ingredient. European Journal of Nutrition \& Food Safety, 200-213. http://dx.doi.org/10.9734/ejnfs/2019/v11i430162

Whigham, L. D., Watras, A. C., \& Schoeller, D. A. (2007). Efficacy of conjugated linoleic acid for reducing fat mass: a meta-analysis in humans. The American Journal of Clinical Nutrition, 85(5), 1203-1211. http://dx.doi.org/10.1093/ajen/85.5.1203

Yang, B., Chen, H., Stanton, C., Ross, R. P., Zhang, H., Chen, Y. Q., \& Chen, W. (2015). Review of the roles of conjugated linoleic acid in health and disease. Journal of Functional Foods, 15, 314-325 http://dx.doi.org/10.1016/j.jff.2015.03.050

Zeng, Y., Liu, P., Yang, X., Li, H., Li, H., Guo, Y., ... Liu, X. (2020). The dietary c9, t11-conjugated linoleic acid enriched from butter reduces breast cancer progression in vivo. Journal of Food Biochemistry, 44(4). http://dx.doi.org/10.1111/jfbc.13163

Zengin, G., Cakmak, Y. S., Guler, G. O., Oguz, E., Aktumsek, A., \& Akin, M. (2011). The effect of pasteurisation temperature on the CLA content and fatty acid composition of white pickled cheese. International Journal of Dairy Technology, 64(4), 509-516. http://dx.doi.org/10.1111/j.1471-0307.2011.00697.x Zhang W., Kakuda, Y., \& Hill, A. R. (2007). Conjugated linoleic acid (CLA) in processed cheese. Milchwissenschaft, 62(2), 174-178.

Zhuang, F., Li, X., Hu, J., Liu, X., Zhang, S., Tang, C., \& Zhou, P. (2018). Effects of casein micellar structure on the stability of milk protein-based conjugated linoleic acid microcapsules. Food Chemistry, 269, 327-334. http://dx.doi.org/10.1016/i.foodchem.2018.07.018

Zlatanos, S., Laskaridis, K., Feist, C., \& Sagredos, A. (2002). CLA content and fatty acid composition of Greek Feta and hard cheeses. Food Chemistry, 78(4), 471-477. http://dx.doi.org/10.1016/s0308-8146(02)00159-0 